\title{
EFEITO ISOLADO DO ANTICORPO MONOCLONAL TRASTUZUMAB (HERCEPTIN⿴) EM UMA PACIENTE COM RECIDIVA LOCAL DE UM CARCINOMA MAMÁRIO COM HIPER-EXPRESSÃo de Cerb-2
}

\section{Auro del Giglio}

Trabalho realizado na Clínica de Oncologia e Hematologia (CLIOH), S. Paulo, SP

Cerca de $30 \%$ dos casos de carcinoma de mama têm hiper-expressão da proteína de membrana Cerb-2'. O trastuzumab é um anticorpo monoclonal específico para a proteína Cerb-2 que tem atividade terapêutica em casos de câncer de mama avançado isoladamente ${ }^{2}$ ou associado à quimioterapia ${ }^{3}$. Esta paciente, já previamente exposta a vários tratamentos quimioterápicos e hormonioterápicos recebeu aplicações semanais de trastuzumab como agente isolado com excelente controle de sua doença por vários meses.

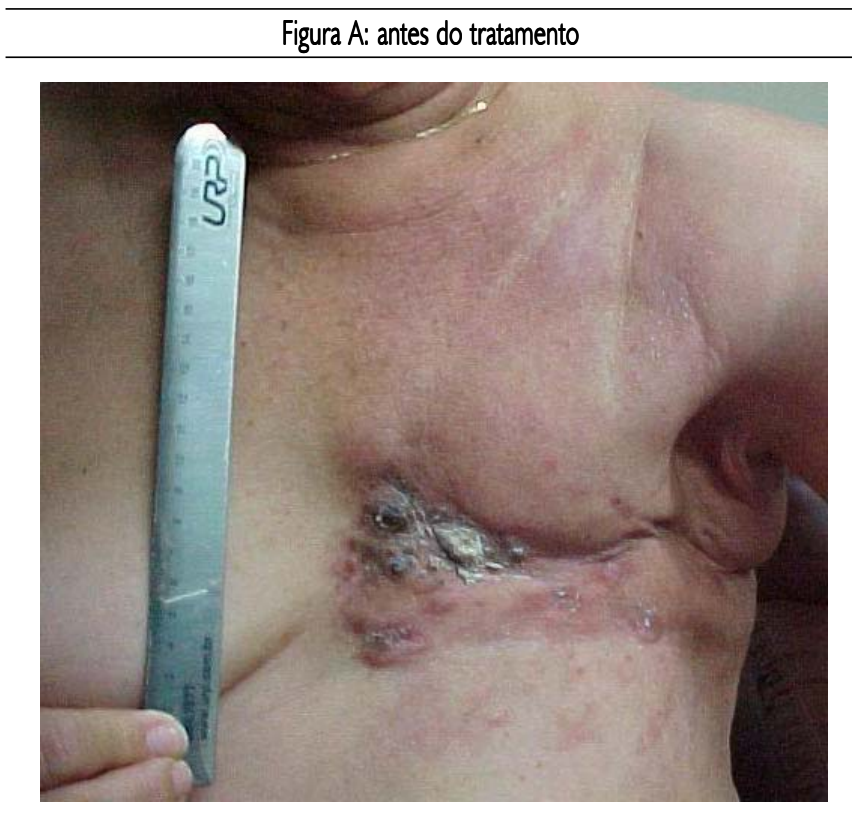

\section{Referências}

I. Yarden Y. Biology of HER2 and its importance in breast cancer. Oncology 200 I;6I(Suppl 2): I - I3.

2. Vogel CL, Cobleigh MA, Tripathy D, Gutheil JC, Harris LN, Fehrenbacher $\mathrm{L}$, et al. Efficacy and safety of trastuzumab as a single agent in first-line treatment of HER2-overexpressing metastatic breast cancer. I Clin Oncol 2002;20(3):719-26.

3. Slamon DJ, Leyland-Jones B, Shak S, Fuchs H, Paton V, Bajamonde $A$, et al. Use of chemotherapy plus a monoclonal antibody against HER2 for metastatic breast cancer that overexpresses HER2. N Engl I Med 2001;344(I I):783-92.

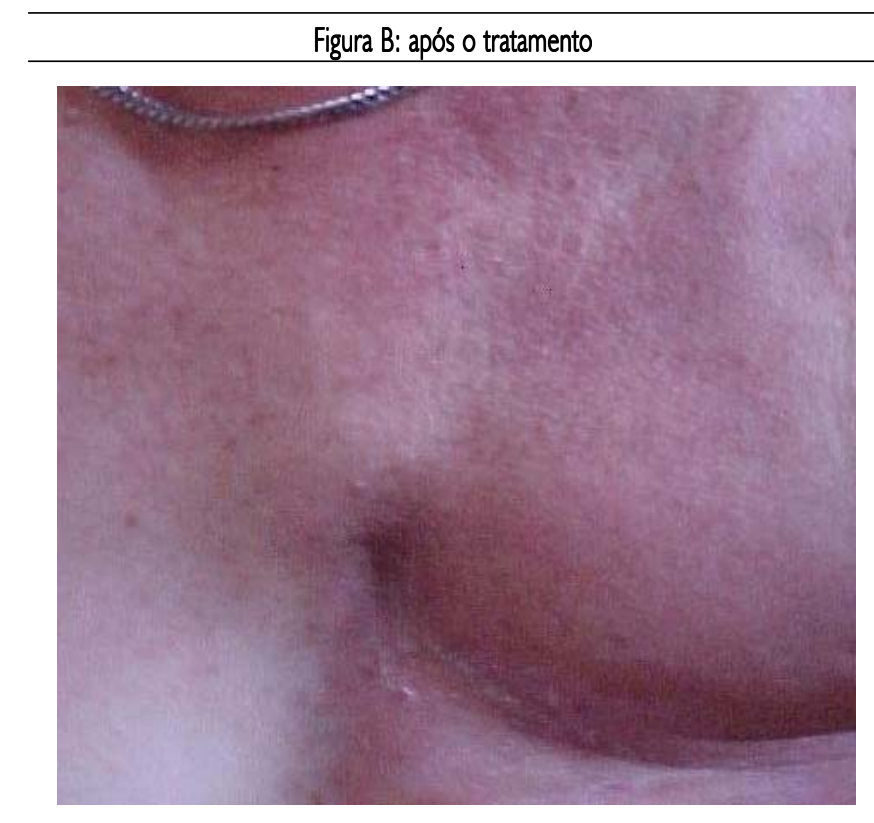

